\title{
THE USE OF SOIL SURVEY REPORTS IN THE APPRAISAL OF FOREST LAND PRODUCTIVITY IN ALBERTA
}

\author{
By P. J. B. DUFFY ${ }^{1}$ \\ INTRODUCTION
}

In Alberta, large acreages of productive forest land fall within map sheets recently published by the National Soil Survey. Extensive portions of the boreal Mixedwood Section are described in reports on the High Prairie and McLennan Sheets (Odynsky et al., 1952) and the Grande Prairie and Sturgeon Lake Sheets (Odynsky et al., 1956) and a part of the Foothills Section is included on the Rocky Mountain House Sheet (Peters and Bowser, 1960). A forest-use evaluation of some aspects of the Soil Survey data, based on the latter report, is the subject of this article.

\section{The Soil Survey}

The Rocky Mountain House Sheet covers approximately 1,600,000 acres in west-central Alberta, one-third of which is in forest. The soil survey of the area was on a reconnaissance scale, with traverses at one mile intervals along road allowances. Aerial photographs were used extensively to establish soil boundary lines between the traversed strips. The mapping unit was the soils series.

In addition to the map of a scale 2 miles to the inch showing location and extent of parent materials, associated soils series and topography, the report contains much information on environmental conditions and on physical and chemical properties of soils from selected profiles. It therefore constitutes a useful general inventory of the soil resource of this area.

\section{Description OF the Area}

Four soil series support merchantable forest stands. These soils, which cover the western third of the Rocky Mountain House Sheet, are described as Podzol Grey Wooded Soils,

"so called because of a secondary profile (podzol-like) which has developed in the $A_{2}$ horizon of the original Grey Wooded profile. Immediately under the leaf mat there is a pinkish white $A_{2}$ horizon being formed. This horizon is usually over one inch in thickness. Immediately below this there is a distinctive brown to reddish brown $B$ horizon formed.

Varying amounts of light grey-brown $A_{2}$ horizon of the Grey Wooded Soil may remain; although in places the reddish brown podzol B sits directly on the blocky Grey Wooded

B. The remainder of the profile resembles the Grey Wooded Soil, that is, it has the heavy textured blocky B horizon". (Peters and Bowser, 1960.)

The four soil series are classified in the Podzolic Soils Order, Grey Wooded Great Group, Bisequa Grey Wooded Sub-Group in the National System of Classifying Canadian Soils (National Soil Survey Committee of Canada, 1960).

The four soils occur on different parent materials and bear different soil series names. The most extensive is the Lobley Loam, a heavy loam soil on well to moderately well drained glacial till. The soil is a stony, sandy

${ }^{1}$ Research Officer, Forest Research Branch, Department of Forestry, Calgary, Alberta. 
loam to clay loam with accumulations of lime at three to four feet depth. The topography is hilly throughout. In well drained situations the Lobley supports good stands of pure lodgepole pine (Pinus contorta Dougl. var. latifolia Engelm). Sometimes on gentle slopes with poor external drainage, black spruce (Picea mariana (Mill.) BSP) and white spruce (Picea glauca (Moench) Voss) are associated with pine. In the absence of fire, a mixedwood forest dominated by white spruce would probably develop.

The Caroline Loam, a silt loam, is a medium textured stone-free lacustrine soil which overlies either a stony till or a sand. The topography is level to gently rolling. The Caroline has fairly good arable qualities and consequently the forest cover is being gradually removed to make way for agricultural development. Lodgepole pine is usually the dominant species in the forest cover but aspen (Populus tremuloides Michx.) may be an associate on dry sites and a black spruce-pine mixture occurs on wet sites.

The Prentice Sandy Loam, or loamy sand is an aeolian soil which occurs as a cap overlying till or coarse, gravelly alluvium. The Prentice soils are usually droughty and, because of the high sand fraction, they may have a poor nutrient status for tree growth. The topography is rolling to gently rolling, often dune-like in appearance. The forest cover is a variable mixture of lodgepole pine, aspen, black spruce, and balsam poplar (Populus balsamifera L.). Where the aeolian cap is deep, the soils are well to excessively drained and the pine-aspen mixture prevails. A thin cap with a shallow water table may support a pine - black spruce - balsam poplar mixture. Pure stands of pine are not common.

The Horburg Sandy Loam is a gravelly soil which ranges in depth from a few inches to two feet on river terraces and outwash plains. The topography is level to gently rolling. The Horburg usually supports well-stocked stands of pure pine but aspen may share the site where the moisture regime is improved.

\section{STUDY METHODS}

In 1959 five $1 / 5$ acre plots were located in 55-year-old pine stands on each soil series. The following data were recorded for each plot:

a) physiographic site and soil profile description.

b) diameter tally of all trees over 0.6" d.b.h.

c) total height of 10 dominant lodgepole pine trees.

d) five relascope readings of basal area per acre (one at the plot centre and at one-half chain distances along the four cardinal directions from the centre).

e) notes on vegetation and stand history.

Mean dominant height of lodgepole pine and basal area in square feet per acre for all species were computed for each soil series. An analysis of variance and multiple range tests (Student-Newman-Keuls) were used to test for significant differences between the respective means and these were corroborated by the "t" test.

\section{Results}

Table 1 shows mean dominant height for pine and mean basal area per acre of all species at age 55 years at breast height for three soil series. Plots 
in the Prentice series are not included in the comparison because of the mixed forest composition and the open nature of the stands.

TABLE 1.

Growth of Well Stocked Stands of Lodgepole Pine at Age 55 Years on Three Soll Series, Rocky Mountain House Sheet, Alberta

\begin{tabular}{|c|c|c|}
\hline Soil Series & Mean Dominant Height (ft.) & $\begin{array}{l}\text { Mean Basal Area Per Acre } \\
\text { All species (sq. } \mathrm{ft.} \text { ) } 1\end{array}$ \\
\hline $\begin{array}{l}\text { Lobley Loam, Heavy Loam } \\
\text { (5 plots) }\end{array}$ & 57.5 & 165.7 \\
\hline Caroline Silt Loam & & \\
\hline $\begin{array}{l}\text { (5 plots) } \\
\text { Horburg Sandy Loam }\end{array}$ & 55.4 & 117.9 \\
\hline (5 plots) & 49.1 & 119.8 \\
\hline
\end{tabular}

${ }^{1}$ From plot tally data.

Note: Vertical lines show "no significant difference."

The dominant height and basal area values for the Lobley series are significantly greater than those on the Horburg Series and these series may be ranked accordingly. The Caroline is more productive than the Horburg in terms of dominant height but not in basal area.

An estimate of merchantable volume in cords per acre may be obtained by multiplying the product of the mean dominant height in feet and the basal area in square feet by the factor .005 . The estimates by soil series are as follows:

$$
\begin{array}{ll}
\text { Lobley } & 47.6 \text { cords, } \\
\text { Caroline } & 32.6 \text { cords, } \\
\text { Horburg } & 29.4 \text { cords. }
\end{array}
$$

In summary, the Lobley series is more productive than the Horburg; and the Caroline produces dominant heights in pine which are similar to those on the Lobley and basal areas which are similar to those on the Horburg.

\section{Discussion and Conclusions}

Variation in growth within a soil series may be so large that prediction of forest yield is difficult, in which case a finer breakdown is needed. The Lobley (till) soil could, for example, be subdivided into phases based on criteria which affect available moisture in the soil. A suitable partition could employ the topographic classes recognized by the National Soil Survey. Currently the independent variables, slope angle, slope length, position on slope, and depth of solum are being tested along with other site factors in an analysis of site components as they are related to growth and development of lodgepole pine. The results of the study may suggest certain regrouping of soil series of topographic classes for better prediction of growth and yield.

The principal value of the soil survey report to the forest manager is the record of the location and extent of the different soil types. In addition, information on the characteristics of the soil and the terrain may be useful in predicting potential forest growth and in planning for planting operations, 
seedbed preparation, cutting methods, and road location. For example, the results shown in Table $I$ indicate that it would be more economical to practice more intensive forest management on stands on the Lobley Series than on the Caroline or the Horburg, because of important differences in the productivity of these soils. Certainly this exploratory study suggests that species composition, tree height, and basal area are related to the soil series of the Rocky Mountain House Sheet as identified by the National Soil Survey. Thus, while the report and map have been drawn up primarily for workers in agriculture, the publication contains much useful information for the forester. It is suggested that the several other soil maps of areas in Alberta are useful references of forest land productivity and management. Further, since additional forest lands are currently being mapped by the Soil Survey, it would seem that co-ordinated soils and forestry field surveys would help to maximize the usefulness of the data and indicate significant correlations of soil types and forest yield.

\section{BIBLIOGRAPHY}

NATIONAL SOIL SURVEY COMMITTEE OF CANADA. 1960. Proceedings of the Fourth National Meeting of the National Soil Survey Committee of Canada. A. Leahey, Chairman. Ontario Agricultural College, Guelph, Ontario. 42 pp.

ODYNSKY, W., A. WYNNYK, and J. D. NEWTON. 1952. Reconnaissance soil survey of the High Prairie and McLennan Sheets. Research Council of Alberta Report No. 63;112 pp. and 2 maps.

1956. Reconnaissance soil survey of the Grande Prairie and Sturgeon Lake Sheets. Research Council of Alberta Report No. 74; 111 pp. and 2 maps.

PETERS, T. W. and W. E. BOWSER. 1960. Soil survey of the Rocky Mountain House Sheet. Alberta Soil Survey Report No. 19: 51 pp. and 3 maps. 